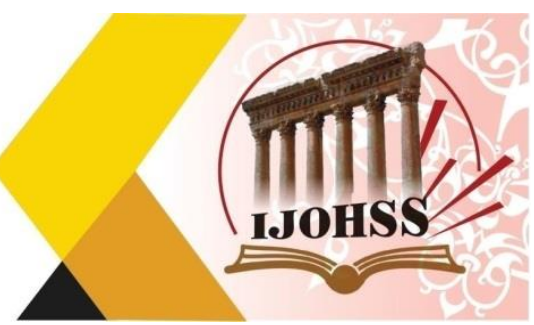

\title{
The Impact of the Extreme Right in the United States of America on the Future of International Relations
}

\author{
1- Assistant Professor \\ Faisal Shallal Abbas \\ University of Baghdad - Iraq \\ Email: faisal.sh@ihcoedu.uobaghdad.edu.iq \\ https://orcid.org/0000-0002-9008-6826 \\ 2- Assistant Professor \\ Majeed Kamil Hamzah \\ University of Baghdad - Iraq \\ Email: majeed.kamel@cofarts.uobaghdad.edu.iq \\ https://orcid.org/0000-0002-5603-4096
}

\begin{abstract}
The eighties and nineties witnessed the remarkable rise of the far-right parties in Europe and the United States of America through the large and unexpected presence in the local and legislative elections, and despite its difference from one country to another, the growth of the extreme right's voice in reality reflects the crisis of Western political systems as a whole. The rise of the extreme right movement is not only due to the current's own strength, or the popular need for it, but rather expresses a deep crisis of the moderate right and the moderate left alike. The policies and ideas of the extreme right affect all political issues and are reflected in the policies of US governments Especially in which extremist members participate by officially adopting the calls of those extremist parties and codifying them through a series of undemocratic laws. The debate over how to interpret the shifts in the behavior of actors in international relations is hardly ceased. For decades, the interpretations of international relations scholars of state behavior have focused on two main trends, the first of which is that international interactions can be explained by analyzing the behaviors of the individual actor (agent) represented by state leaders, The decisions they make are related to their worldview and the belief system and perception of each of them. As for the second trend, the interpretation of international interactions is linked to the analysis of the structure of the international system (structure) that imposes restrictions on the movements of states, so that imposes on them who does what, when and how?
\end{abstract}

Keywords: The Extreme Right, the United States of America, International Relations, Europe, The International System. 


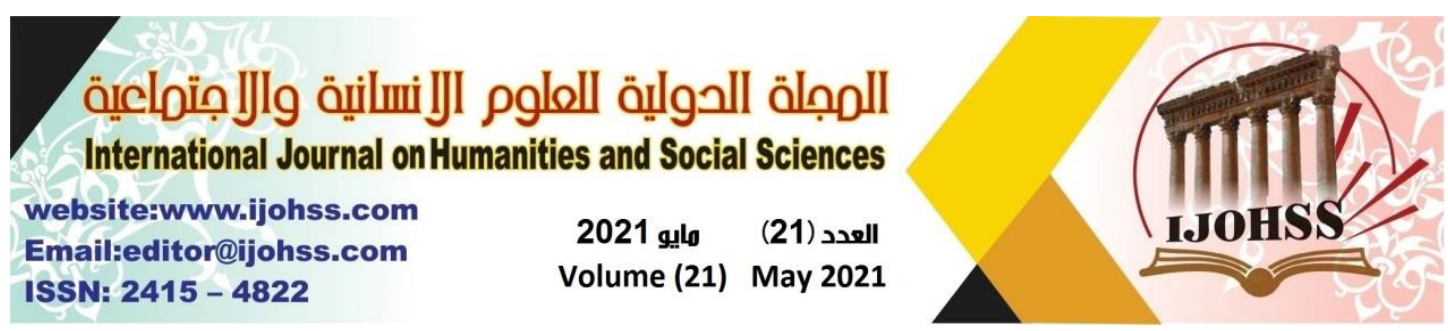

\section{INTRODUCTION:}

After remarkable and unexpected successes for the extreme right-wing parties in most Western European countries, in order to be able to create a kind of chaos within the European political systems, the extreme right has emerged on the international political arena as one of the most important phenomena during the last two decades that has often been characterized by stability, so that it has become difficult for the parties. Traditionalism within the right and the left is to achieve a stable majority as it used to, and it has become forced to cooperate with the extreme right-wing parties, which is what made these parties rise up against their past as mere occasion parties, to be effective, influential and competitive within Western political life. The President of the United States of America "Donald Trump", because of his extreme right-wing legacy represented by his speeches and slogans, to revive this phenomenon in its new form to be a competition and his wrestlers in achieving its desires. To achieve the goal, the study collected information and facts to provide a description of the extreme right phenomenon, and to analyze its effects on the rise of this phenomenon in the United States of America, to find out the implications and implications affecting international politics.

Research problem: It centers on the fact that relations between the countries of the modern world sail in seas choppy waves of political and economic problems, making the agenda of right-wing parties more prominent among Western societies. The research also aims that the rise of the extreme right threatens the fate of political and economic interests not only in the countries in which it is developing, but for the body of the entire international political system, because these organizations and parties adopt strategic, political and economic visions and perceptions that may change the balance of interests that the world has known.

The Hypothesis: The hypothesis that the research seeks to prove is that the future of international relations in light of the rise and growth of extreme right-wing currents, particularly in the United States of America, has many implications for the process of existing transformations in the international system.

\section{The First Topic/ the Extreme Right, the Concept and Factors of Rise}

There is a difficulty in defining a definition of the concept of the extreme right, although some of them decide that their parties represent in reality the defeated national ideology such as (Nazism and fascism), or what is known in Western literature as the (national-socialist) currents known for their racist tendency and their strong dependence on race as a specific and basic ideology in dealing With others and its classification, from here, knowledge of this phenomenon is necessary to arrive at a concept and the factors of its rise.

I - the meaning and concept of right and left in modern political discourse:

The term right is always associated with the term left when talking about the historical origins of its emergence. The two terms appeared at the same time, coinciding with 


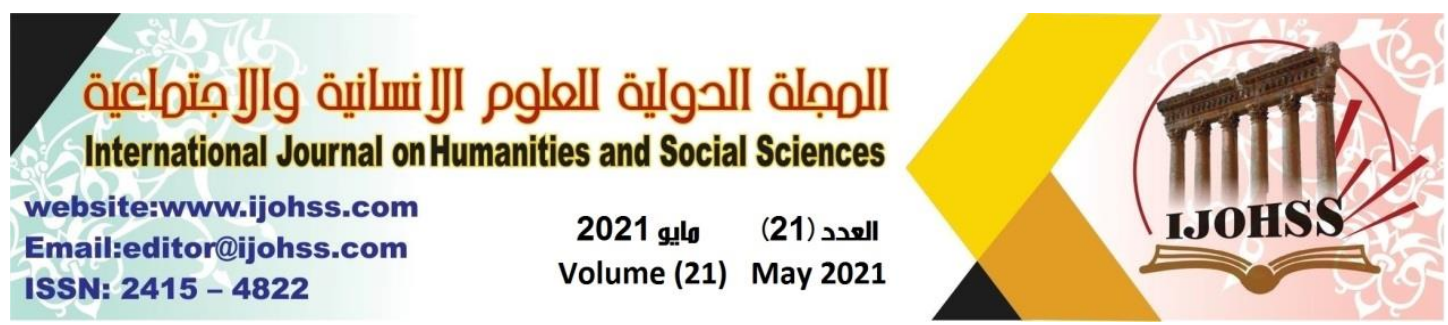

the "French Revolution in 1789" (1). From here, the term (left) began to take on an ideological content or dimension, so the ideology of the left came to express one way or another about this social fact, and when Marxism spread among the intelligentsia and the ranks of workers in Europe, the left was linked in some way to Marxist philosophy itself. And since the men of the Church in general were with the old powers, that is, with the powers that have the reins of economic, social and cultural affairs, that is, with the right, The Church classified religion in the European sense with the right and linked it to it, while the left considered a representative of that working class, and in general, social groups liberated some kind of religious obsessions ${ }^{(2)}$.

Thus, the concept of (left-right) has become a two-dimensional concept, an economic dimension that is mainly determined by the relationship with the means of production (by their ownership: the right, or their non-ownership: the left), and an ideological dimension that is mainly determined by the type of metaphysical view of the universe, the religious view (the right), and the materialistic outlook characterized by workers (the left). In connection with these two dimensions, and with the ideological dimension in particular, two synonyms appeared, for the term (left-right) is the term (progressive-reactionary), so progressiveness became a feature of the left and reactionary a feature of the right ${ }^{(3)}$.

As for the concept of the extreme right, it comes in several linguistic structures that differ from each other, as we will find several names, whether in relation to parties, movements, or all groups of the extreme right, so it may come under the name (the radical right - the radical right) and may respond to us with another term under the name (Far-right) or comes under the term (right-wing extremism), or under the designation (extreme right) or in the name of (populist nationalism), (right-wing radical populism), or (populist radical right), in addition to this, combinations close to what has been mentioned We may find in it a slight difference, whether by advancing one single over another or by limiting a part of the idiomatic structure, and the multiplicity of these conventions refers to one case and a specific phenomenon is the lack of a clear and specific definition ${ }^{(4)}$, One of the most unanimous approaches to

$\left.\left.{ }^{1}\right)\right)$ Saeed Kazem Bishara, The Extremist Right in Europe: A Political-Social Study of Reasons and Dimensions, Unpublished Master Thesis, College of Political Science, Al-Mustansiriya University, Baghdad, 2014, p. 7.

${ }^{2}$ ((Al-Jabri, Extremist Right Parties in Europe: A Study in Ideas and the Political Role, Journal of International Studies, No. (35), 2008, Center for Strategic and International Studies, University of Baghdad, Baghdad, p. 47. Looking also, Nazem Abdel-Wahid Al-Jassour, European Right Parties between Accounts of the Past and Future Prospects, European Papers, Center for International Studies, University of Baghdad, 2000, pp. 4-7

${ }^{3}()$ Rinas Penafi, The Rise of the Extreme Right, Reasons and Implications: An Analytical Study, Arab Democratic Center, Berlin, May 12, 2017, https://democraticac.de/?p=46400

${ }^{4}()$ Peter Bergen, Trump and His Generals: The Cost of Chaos, Penguin Press, December 2019 pp. 44 


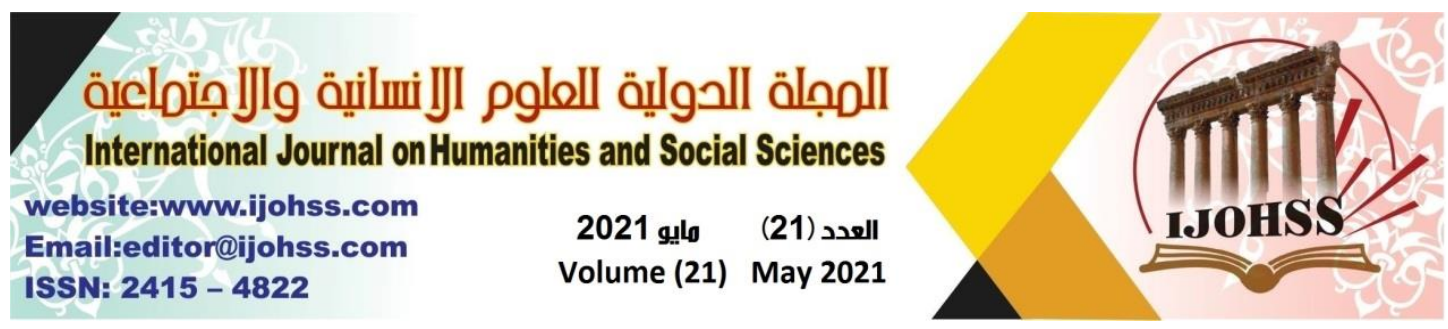

defining the concept of this extreme right is the one presented by the Dutch political science professor (Mayndert Fenema), which came (as parties with a unified ideological pattern, through its anti-immigration and immigrant program, despite some differences in the priorities of internal affairs. They have parties against immigration and immigrants, as migrants are portrayed as a problem in four different forms: the threat of ethno-national identity, the main cause of unemployment and crime, and other manifestations of social insecurity, and are ill-exploited by what the welfare state provides) ${ }^{(5)}$. The researcher (Piero Ignazi) proposes a realistic identification and different conceptual approaches that classify the extreme right. The first is that it must be located far from the traditional debate (right-left), the second is that it must have links to fascism, and the third is that it must defend issues Antidemocratic and anti-capitalist values and policies; That is, it should be against the system $^{(6)}$.

The researcher (Hans-George Batz) offers a broader approach to the extreme right, which he calls right-wing populist parties. These parties that criticize the economic and social policies of Western democracies without attacking their foundations; So that it rejects individual equality, focuses on ethnic homogeneity, and detests immigrants. They are parties that believe in high centrality and a hierarchical system based on the charismatic personality of the leader, and use populism as an effective method for political marketing ${ }^{(7)}$.

\section{II- Factors and causes of the rise of the extreme right:}

There are many factors that have contributed to the rise of the extreme right in recent years, including internal factors related to the economic, political, social and cultural reality of the West, including external factors related to changing international policies, to reflect the phenomenon of the existence of extreme rightwing groups or movements in some countries from the immune deficit of traditional parties., Which recently seemed incapable of controlling the behavior of these movements, despite the issuance of many laws that allow pursuing and restricting them, but with the escalation of crimes and violence and the development of hate speech against foreigners and immigrants, The decision-makers pushed to use

${ }^{5}($ (Right-wing current in the West: Ascension and Influence, Political Papers, Strategic Thought Center for Studies, Beirut, 2018, p. 4.

${ }^{6}($ )Rabeh Zoghouni, Islamophobia and the Rise of the Extremist Right in Europe: Sociocultural Approach, Arab Future Magazine, Volume (36), No. (421), Center for Arabic Unity Studies, Beirut, March 31, 2014, p. 124.

$\left.{ }^{7}()\right)$ Maurice Devergie, Political Parties, Translation: Ali Muqallad and Abdel-Hassan Saad, Dar Al-Nahar Publishing, Beirut, 1983, p. 5, and also looks at: Abu Bakr Al-Desouki, The Dialectical Relationship between Islamophobia and the European Right, Journal of International Politics, No. (208), , Al-Ahram Foundation, Cairo, April 2017, p. 85. 


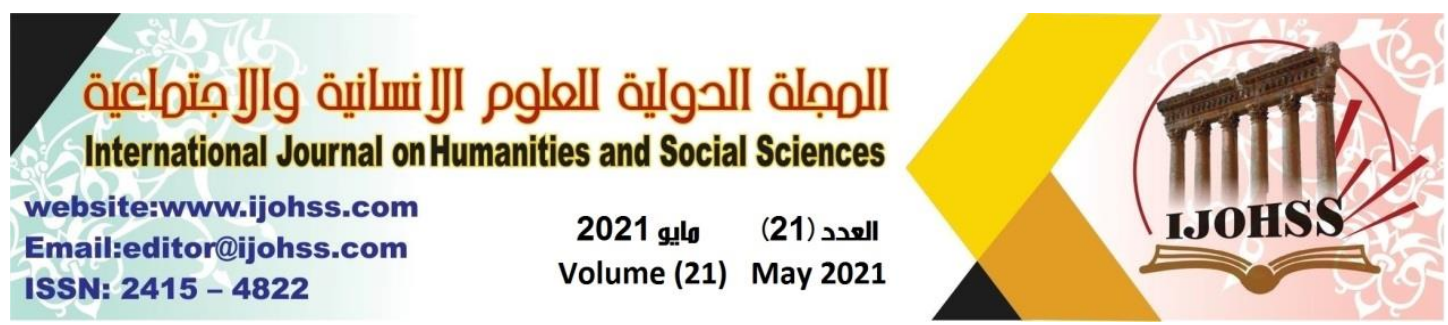

defensive mechanisms to limit the effects of crimes, and to descend upon some of the wishes of the right-wing parties to include them in parliamentary seats ${ }^{(8)}$.

In general, observers differed in agreeing on the behavior and path of right-wing parties as a sustainable phenomenon more than a temporary boom that escalated by the principle of influence from the decline and failure of other parties. It failed in some places to achieve economic, political and social breakthroughs. All this constituted an excuse for right-wing forces to exploit these loopholes to rise at their expense $^{(9)}$.

Many researchers have tried to arrive at objective explanations for the rise of rightwing currents, and theoretical approaches have been developed that try to explain the phenomenon and facilitate its understanding, namely: ${ }^{(\mathbf{1 0})}$

1- Relative deprivation theory: It tends to explain the rise of the extreme right with the desire of certain groups to protest against what they consider to be a subsequent harm to them as a result of changes in economic and social conditions.

2- The new policy theory: Its owners believe that traditional parties are no longer qualified to respond to the problems presented by current societies, and that the political climate tends gradually to weaken traditional party ties.

3- Social demand theory: This theory, which is close to its predecessor and complementary to it, attributes that the electoral success of the extreme right reflects the coincidence of its speech to the whims of large social sectors that have known in recent decades an increasing spread of ethnic and cultural intolerance feelings, xenophobia and boredom from the values of freedom, equality and human solidarity. From here, many political studies of the rise of the phenomenon of the extreme right have tried to identify the factors and causes of this growth and rise to the existence of deeper explanations that led to the emergence of this phenomenon, including the following:

1- Political reasons: Some interpretive entries suggest a link between the increasing rise of extreme right-wing parties and factors related to the institutional aspect of political life, and in this regard we find several approaches. The first of these approaches is the theory of punitive or protest voting, which explains the increase in voting in various European elections in favor of the forces of the extreme right as an

${ }^{8}()$ The rise of the extreme right in Europe: the most prominent factors, personalities and ideas, Directorate of Strategic Studies, No. (35), Consultative Center for Studies and Documentation, Beirut, May 2019, p. 8.

${ }^{9}$ () Ulrich Beck, Power and Counter-Authority in the Era of Globalization, translated by George Kattoura and Elham Shaarani, The Eastern Library, Beirut, 2010, pp. 11-12

${ }^{10}$ () Mona Khwais, The Men of Balconies An Analytical Study of the Populist Phenomenon, Dar Al-Farabi, Beirut, 2012, pp. 27-30. 


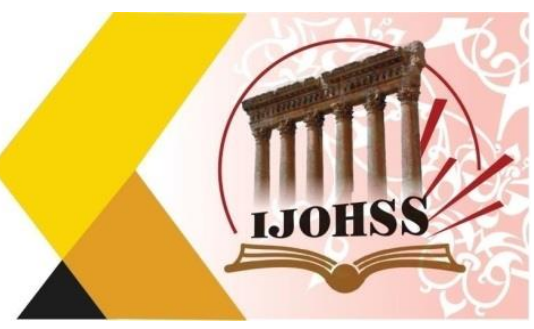

expression of the widening circle of discontent and dissatisfaction with the policies of the right and left in particular. ${ }^{(11)}$

2- Cultural and social reasons: Cultural factors related to identity are among the most important reasons for the rise of the extreme right movements, which make the issue of identity in its ethnic and religious dimensions the most important pillar of its political discourse, especially since issues of identity and nationalism are rooted in human and political thought and in all countries and peoples of the world. The national political thought was and still is a living and influential factor in determining the stances of states and directing their policies under multiple and varied names with one and common significance (national goals - national interest - national security): (12)

- The large waves of immigration that Western countries are witnessing from the third world countries, which increased with the deterioration of the security situation in the Middle East.

- New globalization trends that pose a threat to local cultures.

- The return of national thought and identity issues.

3- Economic reasons: The economic factor is a major cause of the electoral rise, by exploiting the repercussions of the global economic crisis in $2008 \mathrm{AD}$, the eurozone crisis, mortgage in the United States of America, unemployment, rising public debt rates and declining levels of economic growth ${ }^{(\mathbf{1 3})}$.

\section{The Second Topic।The Effect of the Extreme Right on the International Policy of the United States of America}

In recent years, there has been a clear rise of the parties of the extreme right, especially in the United States, due to the availability of focus on several issues, such as: the turmoil of the American leadership, and the complexities of the transfer of power to the Asian continent due to the problems of the interior in parallel with the formation of disturbing features of the "post-globalization" stage and anticipation of unexpected risks The shift in the roles of states and leaderships as a result of the turmoil in the relationship between the state, society and markets, and the increase in economic pressures resulting from the domination of the wealthy, inequality and the complex effects of rapid technological progress on the economy, society and security, Among its results was the arrival of "Donald Trump" to the presidency of the largest and most important country in the world, the United States of America, thus posing a threat not only to the fate of political and economic interests in these countries, but to

${ }^{11}$ () Yemeni Atef Mohamed, The Rise of the Extremist Right Parties in Europe: A Case Study of France in the Period "1984 - 2017, Arab Democratic Center, Berlin, August 19, 2019, see: https://democraticac.de/?p=62037

${ }^{12}$ () The Rise of the Extreme Right in Europe: The Most Important Factors, Characters, and Ideas, previously mentioned source, p. 6.

${ }^{13}$ () Rabeh Zoghouni, Islamophobia and the Rise of the Extremist Right in Europe: A Sociocultural Approach, previously mentioned source, p. 128. 


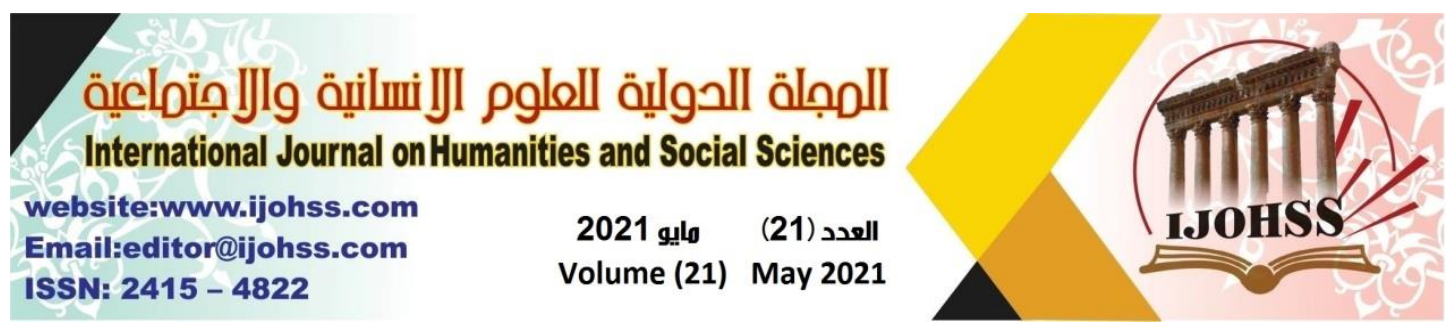

the body of the entire global system, according to what these organizations and parties adopt for strategic, political and economic visions and perceptions. The balance of interests that the world has known for more than three decades has changed to some extent. $^{(14)}$

\section{I- Indicators of the rise of the extreme right in the United States of America:}

First of all, there is the fact that the forces and currents that constitute the main pillar of the American extreme right in their policies and stances towards internal and external issues that the American society will face, have historically benefited from two important matters and each of them is linked to the other. The first thing: that the traditional view on the part of most Americans towards the outside world, including In that, in the most times of scientific progress and technological development that the world is currently experiencing, it is a mixture of the feeling that this world is very far from them and does not affect much of them. As for the second: on which the forces of the extreme right have bet on The American citizen is that what matters to the American citizen in the first place and means a lot to him in the first place is the improvement of his economic and social conditions and the standards of living for him and his family in general, with all that this implies in terms of reducing his tax burdens, an increase in his income, and obtaining a job in order to avoid being counted among or those included in Unemployment table. The extreme right has always used these two elements to intimidate the American citizen from the alternative $^{(\mathbf{1 5})}$.

The United States of America has known this phenomenon historically since the early nineteenth century, and it has embodied in two main currents: The first is the one that directs his anger at the ruling elites and economic companies related to the federal government in defense of the interests of workers, men and women who do basic work in the country and adopt the defense of the people. Which means for him the working classes, the peasants and farmers, and this trend belongs to the liberal orientation that has a civic nationalism that is based on human equality in the right to life and freedom to achieve happiness. As for the second, which directs its criticism and anger at the elites, big companies and federal governments under the pretext of undermining the economic interests of individuals and threatening basic freedoms, this trend adopts the concept of the people with a racist nationalist content, referring to the white citizens of European origins ${ }^{(\mathbf{1 6})}$.

${ }^{14}$ ( (Russell Muirhead and Nancy L Rosenblum, A Lot of People Are Saying: The New Conspiracism and the Assault on Democracy, Princeton, 2019

${ }^{15}()$ Dominic Vidal, European Extremist Right Movements: Strategies and Identities, in the book, Situations of the World 2012, new players ... and a new reality, translation: Hoda Munqas, Arab Thought Foundation, Beirut, 2012, p. 81.

${ }^{16}$ ()Noman Abdul-Razzaq Al-Samarrai, targeting Arabs and Muslims, Al-Faisal Magazine, Issue (1268), King Faisal Center for Research and Islamic Studies, Riyadh, February / March 2007, p. 94. 


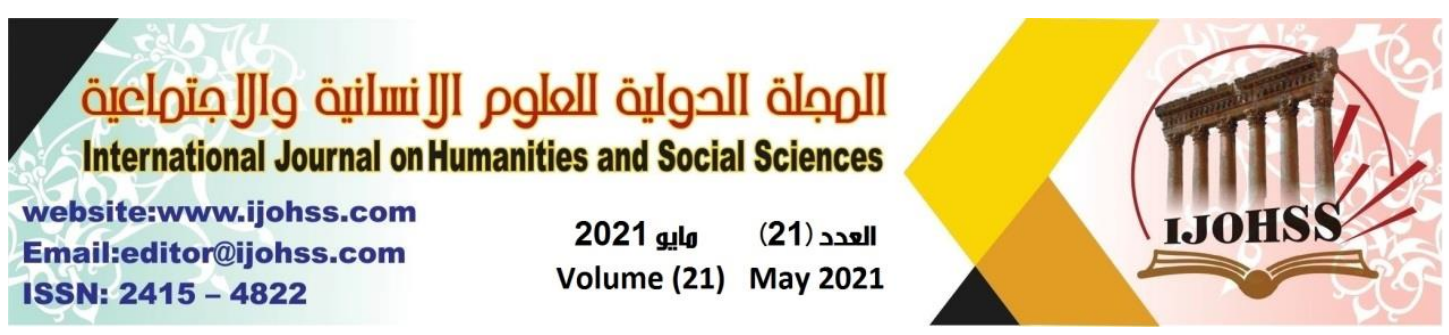

The United States of America has passed through parties, currents and personalities known for their characterization of the extreme right rather than organizational parties, including the following: ${ }^{(17)}$

1- The "Jacksonian": which is attributed to the seventh president of the United States of America, who is (Andrew Jackson), who ruled between (1829-1837), who was famous for defending ordinary citizens who do not have wealth, and the National Bank in the United States of America opposed the control of the rich over it And because it does not serve the poor. And this political and intellectual current attributed to President "Jackson" is still present in American political circles today: ${ }^{\mathbf{( 1 8 )}}$

2- The American People's Party: which was founded in 1890 by a group of Latinspeaking American journalists and sought to liberate the political system from the grip of the power of money, and most of its activity was in the south and west, and it criticizes industrial and financial monopolies that lead to the impoverishment of citizens, and most of its societal bases were farmers The poor, carrying progressive ideas hostile to the elites, as well as seeking to expand power in the federal government to serve simple citizens. As this party contemplated a nationalist racist movement hostile to the Chinese presence in the United States of America led by the white middle working class and was known for its anti-foreigners, specifically the Chinese and Japanese, and this movement's pressure on Congress culminated in the issuance of a law in 1882, the entry of Chinese and Japanese to the United States is prohibited under the pretext that they pose a threat to its security, and more than 112,000 Japanese have been forcibly evacuated. ${ }^{(19)}$

3- The Tea Party: It is a (racist) political group that emerged in the wake of the global economic crisis in $2008 \mathrm{CE}$, and appeared specifically in 2009, after the intervention of the federal government to rescue financial institutions and major companies according to a vision based on the support of banks and major companies to resume growth and increase employment through what was called a package Economic rescue during the era of President (Barack Obama), and the Tea Party is not a party in the conventional sense, but rather an umbrella or alliance for a group of conservative Yemeni organizations and personalities: ${ }^{(20)}$

${ }^{17}$ () Simon Reid-Henry, Empire of Democracy: The Remaking of the West Since the Cold War, 1971-2017, Simon \& Schuster, 2019

${ }^{18}$ () Amin Saadawi and Masoud El-Sassi, The Ascension of Right Populations in the West 2016/2017 AD - USA - Model - Unpublished Master Thesis, Faculty of Law and Political Science, University of the Martyr Hama Lakhdar - El-Wadi, Algeria, 2018, p. 67

${ }^{19}$ () Sherine Hamed Fahmy, The Rise of the Extremist Right in Europe Between Cultural and Political and Economic Interpretation, The Civilization Center for Studies and Research, Cairo, considers: http://hadaracenter.com/pdfs/

${ }^{20}$ () Naji Abdel-Nour, Muslim Communities in Europe and the extent of their integration into political work in light of the rise of extreme right parties, in the book Islamophobia in Europe: Discourse and Practice, Arab Democratic Center for Strategic, Political and Economic Studies, Berlin, 2019, pp. 149-150. 


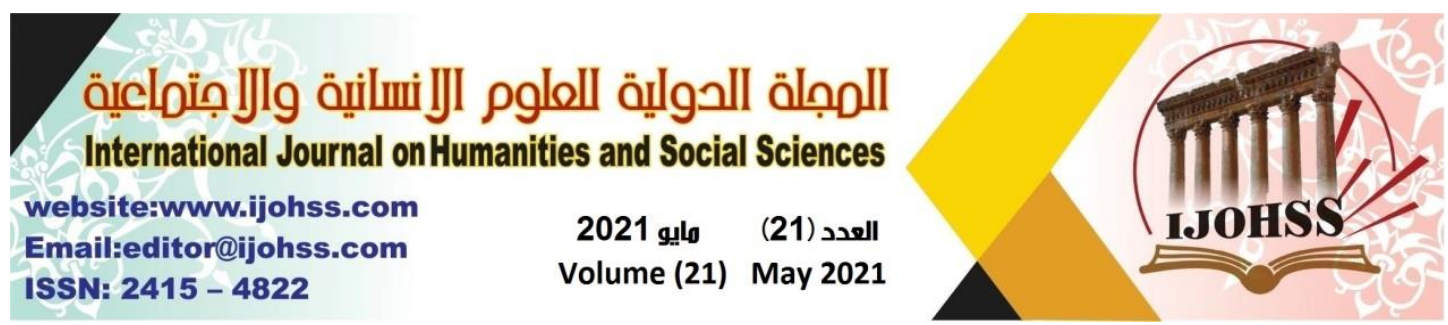

4- President "Donald Trump": The victory of US President "Donald Trump" in the elections of November 8, 2016, is the revival and growth of hopes of the phenomenon of the extreme right in the United States of America in particular and the world in general, and "Trump" is a conservative, ultra-nationalist and distinguished by his faith. What he calls for, he adopted in his speech a style that tends to the extreme right and addresses the emotions of the masses, not their minds. The political science professor (Shervin Malikzadeh) says ("Trump" comes from the world of talented populists, a world of his pioneers who have unnatural abilities to understand peoples' moods and points Weakness, control and direction, with Trump's distinction of believing in what they are called to. ${ }^{(21)}$

"Trump", like other leaders of the extreme right, presented himself as a defender of the societal will, pledging to embody it on the ground in a speech hostile to elites and institutions, and directed a hostile speech to immigrants, especially illegal immigrants, to protect Americans from drugs and crime, as well as direct speeches to white Americans as they are the true people of America for the revival of the soul Conservative America with Christian roots, opposition to same-sex marriage and abortion, and support for carrying weapons, and focused on opposing radical Islam and protecting America from it, promising Americans to eliminate it. ${ }^{(22)}$

"Trump's" ideas are an extension of the ideas of former President (Andrew Jackson) by focusing on the interest of the American citizen and the realization of the American dream in the United States. He does not believe in the global message of America or its role in spreading democracy, so his project summed it up in the phrase (America first) through which he seeks to pressure and reduce The American liberal situation at home and abroad, for exporting the principles of democracy and pluralism to countries in crisis is a contradiction to the "Trump" project, as the world is made, according to his view, of competitors and enemies who have benefited from the generosity of the United States of America under the globalization system in rebuilding their countries, protecting their security and achieving their interests , Reflecting the context of "Trump" foreign policy, the necessity of growing nationalism that aims to achieve the welfare of the United States and transcend globalization. Which means reviving the glories of conservative right-wing American thought based on freedom and conservative Christian teachings, which attracted Americans from the middle class despite the fact that the bases of the Republican Party historically belong to the wealthy classes and he is a wealthy businessman ${ }^{\text {(23) }}$.

${ }^{21}$ () Yahya Saeed Qaoud and Ola Amer Al-Jaab, US National Security Document 2017 An Analytical Reading of Donald Trump's Strategy, Strategic Readings, Issue (20), Palestinian Planning Center, Palestine Liberation Organization, Gaza, April 2018, p. 21.

${ }^{22}$ () Ahmed Haider Abdul-Ridha, The UK's withdrawal from the European Union, its mechanisms and effects, unpublished Master Thesis, Faculty of Law and Political Science, Beirut Arab University, Beirut, 2019, p. 33.

${ }^{23}$ () Mansour Hussain, The Rise of the Extremist Right in Europe, Progressive Forum Kingdom of Bahrain, January 9, 2017, see: http://www.altaqadomi.org/?p=1311 


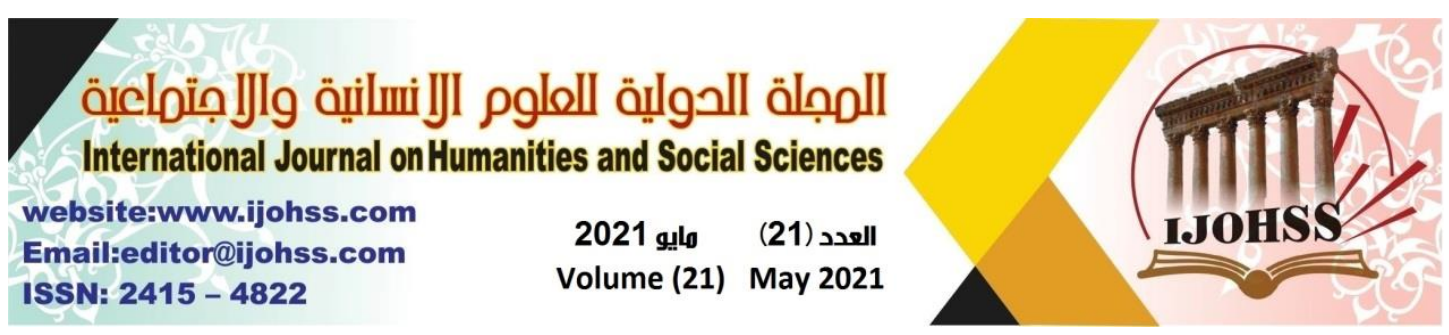

There are two main considerations for "Donald Trump" winning the US presidency. The first is internal, as "Trump" represented the Republican Party and the new vision of American internal crises, and the mechanisms for dealing with them. The second is external, as the extreme right, after the crises of the Western world, has become powerful, influential and successful in European parliaments, due to its new populist rhetoric, which reassures the masses of solving all social problems, especially economic ones. ${ }^{(24)}$

II- The American vision under the rule of the extreme right for its international relations (President "Trump" 2016-2020):

It is possible to record some constants that represent "Trump's" vision regarding the international system and the major issues in the world, and that this vision has been greatly reflected in many of the policies adopted by his administration, as it represents the US National Security Strategy, issued on December 18, 2017, ${ }^{(25)}$ The speech of the US President before the United Nations General Assembly in September 2018, in addition to many other statements and speeches, is a main source for learning about Trump's vision of the world, and the most important features of this vision can be summarized in the following points: ${ }^{(26)}$

A- A dangerous world: "Trump's" vision of the world is close to the ideas of the realist school of international relations, which views the international environment as being competitive in which the state is in conflict, based on its national interests. Trump indicated in a speech to the United Nations Working Assembly in September 2018, that his country adopts a realistic approach in its policy, and the United States' National Security Strategy indicates in its front pages that the United States is facing a very dangerous world, full of a wide range of threats that have intensified in recent years, including the emergence of rivalry of the United States and seeks to undermine American interests All over the world, as well as what are called (rogue regimes) that are based By developing nuclear weapons and missiles to threaten the entire world, and extremist Islamic terror groups that control large swaths of the Middle East.

B- Intervention or isolationism: He includes some "Trump" policies within the school of the American president (Andrew Jackson), who has developed a worldview that sees the international community as a world of Hobbesian anarchy, in which as a matter it is imperative that Washington not intervene as much as it is required of it to prepare to defend itself enthusiastically Whenever its interests are at stake, in other words, isolationism is the rule, but firm military intervention is appropriate when

${ }^{24}$ () Patrick Diamond, The Crisis of Globalization: Democracy, Capitalism and Inequality in the Twenty-First Century, IB Tauris, 2019

${ }^{25}$ () Abu Bakr El-Desouky, Trump's America .. Profit and Loss Accounts, International Politics Journal, No. (215), Al-Ahram Foundation, Cairo, January 2019, p. 82.

${ }^{26}$ () For more see: Mohamed Kamal, Trump and the future of the international system, Journal of International Politics, No. (215), Al-Ahram Foundation, Cairo, January 2019, pp. 88-90. Likewise, it is considered in: Yahya Saeed Qaoud and Ola Amer Al-Jaab ,0, previously mentioned source, p. 140 


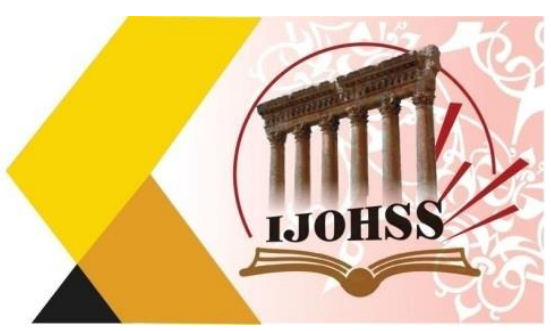

necessary to defend the economic and security interests of the country. However, "Trump" policies reflect a pragmatic approach towards the allies, which devotes an American foreign policy that is not linked to any fixed and unified traditional frame of reference to understand and interpret it. And from the nationalist trend, "Trump" believes in the idea of isolationism, in the sense that the United States must strictly select the issues it cares about in its foreign policy, as for all others, it must be subject to the principle of isolation. ${ }^{(27)}$

C- The return of competition between great powers: The "Trump" administration's national security document talks about the return of the phenomenon of competition between the great powers, explicitly referring to China and Russia, and the document describes them as two countries that seek to review and restore the current international order, through the use of technology, propaganda, and coercion. To form a world opposed to the interests and values of the United States, and try to undermine American security and prosperity, by controlling information and data, and seeking to make economies less free and less fair, as well as developing advanced weapons and capabilities that could threaten the vital infrastructure and leadership mechanisms in the United States of America.

D- Protectionism: "Trump" does not hesitate to make the moral justification a motive for consolidating a protectionist policy that links US foreign trade with the need for commercial justice, which imposes the submission of commercial partners, led by the "European Union" and the "NAFTA" countries, to controls that contribute to Washington's achievement of a trade surplus and preserves jobs there. Thus, "Trump's" speech falls within the context of expediency that liberates the means from all restrictions to achieve the desired goal, even if it is at the expense of a fair and unequal global economy, which is evident in his endeavor to retreat from Washington's foreign commitments, his threat to global trade balances and his opposition to US funding for "United Nations" projects Due to global warming and climate change, economic justice for "Trump" is linked to achieving public welfare, albeit at the expense of minorities. ${ }^{(28)}$

E- The threat from rogue states: President "Trump's" administration adopts confronting the so-called rogue states, and puts Iran in the center of these countries, which "Trump" describes as the leading country in the world in sponsoring terrorism, and is taking advantage of instability to expand its influence through partners and proxies. And the provision of weapons and financing, as it continues to develop more capable ballistic missiles, as well as developing its intelligence capabilities and implementing electronic activities that work to perpetuate the cycle of violence in the "Middle East" region.

${ }^{27}$ () Nicholas Lardy, The State Strikes Back: The End of Economic Reform in China, Peterson Institute for International Economics, 2019

${ }^{28}$ () Bruno Maçães, The Dawn of Eurasia: On the Trail of the New World Order, Penguin Random House, 2018 


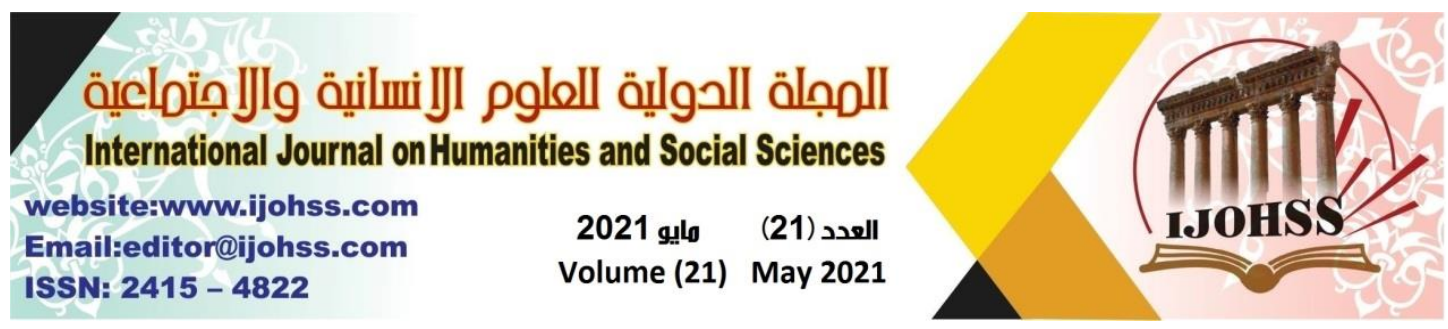

F- Patriotism, not globalization: In his speech to the "United Nations" General Assembly, "Trump" stated: "We reject the ideology of globalization, and we embrace a patriotic faith," and he attacked the foundations of the liberal international order that his country had adopted since the end of the Second Scientific War, namely freedom of trade, And the role of international organizations, and called for the restoration of sovereignty and national interests, and directed his criticism of the former leaders of the United States for what he called their participation in building nations abroad, while they failed to build and renew the country at home, diverted their eyes from the future of the United States and lost their faith in American greatness. ${ }^{(29)}$

G- Sharing of burdens with allies: The US national security document referred to the importance of sharing burdens with allies, and Trump declared: "We made it clear that the rich countries should pay the United States the costs of defending it. This is a great departure from what was happening, but it is fair. It is necessary for our country, and necessary for the American taxpayers and for our own thinking process".

H- The winning deal: "Trump" is working through his speech to present himself (as a man of a bargain) and the main negotiator who can translate his success in the business world into politics. Relative to the rest of the parties, as there is no ethical approach towards the allies and the rest of the world, just as it is possible for any ideology, according to pragmatism alone is the basis for achieving US interests, which requires renegotiation again on trade agreements or otherwise concluded by the United States to obtain a profitable deal. ${ }^{(30)}$

\section{The Third Topic $\backslash$ A Vision for the Impact of the Extreme Right Policy on the International Level}

The rise of the extremist Yemen provokes strong reactions in Western political and cultural circles, and positions vary according to political trends. The political left appears to be more critical of the extreme right, and more firm to oppose it, while traditional (liberal) Yemen is lenient in its dealings with supporters of this trend, and avoids describing them as extremists. Or the two elements in order to win them over to his side, because the extremist right-wing voters usually cast their votes for the traditional right in the absence of representatives of their favorite parties, and then traditional Yemen pursues a policy of containment, because the extremist wave dissipates and increases its electoral weight. The first basic meeting point between the majority of politicians and intellectuals may be to avoid describing the extremist

${ }^{29}$ () For more, see: The Rise of the Extremist Right in Europe: The Most Important Factors, Characters, and Ideas, a previously mentioned source, p. 9. See also: The Right Right in the West Ascension and Influence, a previously mentioned source, p. 8.

${ }^{30}$ () Robert Kaplan, The Return of Marco Polo's World: War, Strategy, and American Interests in the Twenty-First Century, Random House, 2018 


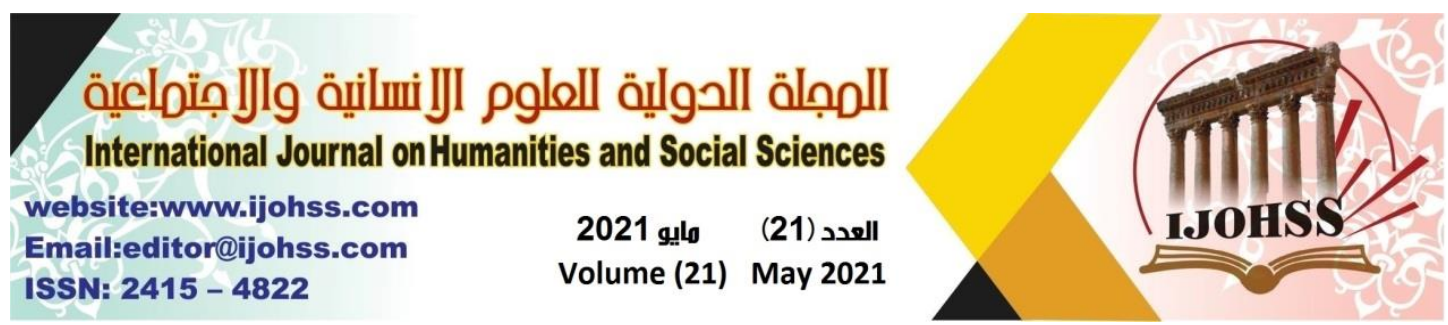

right-wing voters with the two elements, as if they want to follow a direction whose purpose is to understand and understand the behavior of most of these people to get them out of the circle of extremism. The second relates to their exclusion from the hypothesis of banning far-right parties on the grounds that the best way to combat their influence is to address the problems that feed them. ${ }^{(31)}$

Two trends of opinion emerge about the impact of the rise of the extreme right. The first is negative, and it emphasizes the damage that the tolerance model of the modern nation-state may inflict. Its repercussions will be catastrophic if it continues, because right-wing extremist forces are compulsorily identifying the peoples of each state and thus excluding everyone who does not belong to this state. This threatens the project of a united Europe that the continent has been striving to achieve since the end of World War II. As for the positive trend, which is based on the degree of awareness of today's youth, who have grown up in the light of prosperity, freedom, peace, democracy and human rights. This group will feel a great danger in the event of the rise of these extremist currents, and therefore they will be rejected and excluded from society. ${ }^{(32)}$

Therefore, the rise of the extreme right will not be limited to the borders of a region in itself, but will drag the world with it in its bloody endeavors, and this time the ordeal will be greater, because Muslims have become an important component of Western societies, which will drag the world into a massive bloody conflict. The painful thing is that the tendency towards international action after the Second World War within the "United Nations" Foundation did not eliminate the causes of internal tensions in Western societies and elsewhere, and despite the agreement of the countries of the world on a large package of international conventions and laws that govern world affairs in times of peace and war, this It was not forbidden to jump on it and descend towards the roads leading back and possibly war. Moreover, this bundle of charters gradually lost its influence in public life, and even the international institutions that were established in subsequent decades. Like the International Court of Justice and human rights institutions, their roles have retreated. Indeed, the "United Nations" itself suffers from poor performance after being subjected to the blackmail of hostile states to its policies, and the "United Nations'" general security has lost real power and is subject to political pressure, especially from Western countries. ${ }^{(33)}$

${ }^{31}$ () Azmi Bishara, Rise of the Right and Importing the Clash of Civilizations into the Interior: When Democracy Brings Antipods to Liberalism, Arab Politics Magazine, Issue (23), Arab Center for Research and Policy Studies, Doha, November 2016, p. 8

${ }^{32}$ () Yaman Annan, the implications of the rise of the extreme right in Europe, research papers, Al-Badil Center for Planning and Strategic Studies, Amman, 19 December 2016.

${ }^{33}$ () Walid Jasad Al-Zaidi, The Consequences of the emergence of populism in the West, Arab Thought Foundation, Saudi Arabia, May 8, 2019, see: https://arabthought.org/. Likewise, it looks at: the Charter of Manahi Al-Issawi, the growth of populist currents between excessive democracy and government failure, Center for Strategic Studies / Department of 


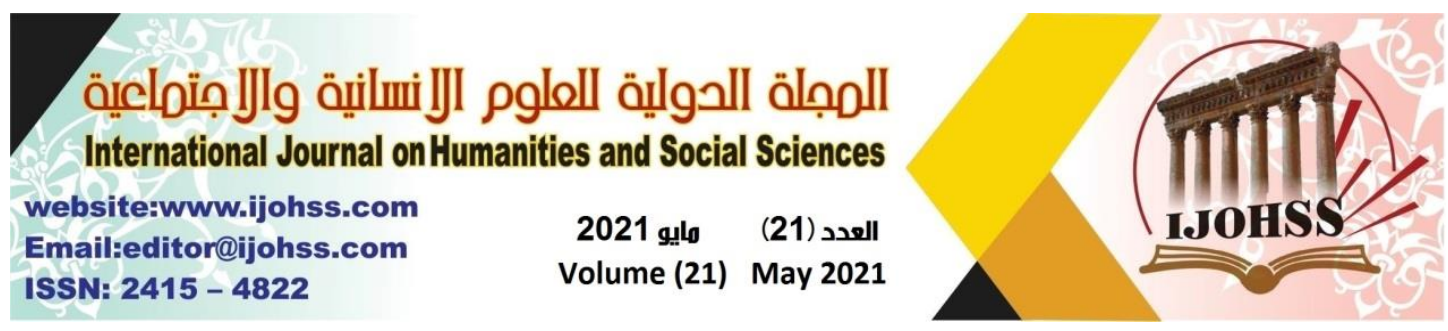

The effects and repercussions of the rise of the extreme right in the United States of America can be summarized internationally through the following:

1 - The rising tide of fanatic extremist religiously, nationally or ethnically: It has spread in many countries of the world, including the West, and each of them considers the others or some of them its enemies, and presents the extremism of its enemies as an argument and justification for its extremism. Each team blames others, disavows fanaticism, and even claims self-defense, to attract more fans to its class. ${ }^{(34)}$

2- Its implications in the subjectivity of human societies: which is summarized by the fact that the collective mind of human groups tends, in part, to search for the easiest and closest interpretation to direct personal observation of the problems facing it, and is alienated from realistic, objective and scientific explanations, because they are difficult and complex interpretations that require effort and level High knowledge; This trend towards "collective naivety" increases when the role of the intellectual elite, and the media and educational institutions, whose most important task is to maintain an acceptable level of collective consciousness, recedes. The rush to build a new world order, by the Western camp, within a vision of rapid profit and full control over the world, the emergence of conflict with the camp of China and Russia and emerging economies, the revolution of communications and human communication, and the chaos of the media, created a suitable environment in most countries of the world for the rise of extreme right-wing thought Whether it is religious, sectarian, national or racial extremism; And all forms of this extremism feed on each other and grow cooperatively with each other, whether through hostility As hostility to rightwing Western extremism and jihadist Islamic extremism; Or out of alliance, as happened between the far-right western parties. ${ }^{(35)}$

3- Revoking international agreements: The strongest manifestations of the new world order emerged through the introduction of several international agreements on trade and investments, the largest of which was the Trans-Atlas Trade and Investment Partnership (TTIP) agreement between the United States of America and the "European Union", and it is the largest economic agreement in history, after the elections. 2016 US presidency, "Trump" announced the suspension of negotiations on this agreement "because he does not like it"; The same policy was repeated with the Trans-Pacific Partnership Agreement (TPP). This agreement was launched by the US administration in 2015 to penetrate Chinese control over the arena of Pacific

\footnotetext{
International Studies, University of Karbala, July 2016, seen: http://kerbalacss.uokerbala.edu.iq/

${ }^{34}$ () Muhammad Al-Hajiri, Dialogue with Ali Harb, Al-Faisal Magazine, Issues (479-480), King Faisal Center for Research and Islamic Studies, Riyadh, September 2016, p. 107. For more, see Sherif Nessim Qaltet Bakhit, the refugee crisis and the rise of the extreme right in Europe, European Center for Counter-Terrorism and Intelligence Studies, Germany, July 13, 2018. https://www.europarabct.com/

${ }^{35}$ () Maram Zeia, the European-American right ... a bridge or a dilemma?, Journal of International Politics, No. (215), Al-Ahram Foundation, Cairo, January 2019, pp. 123-123.
} 


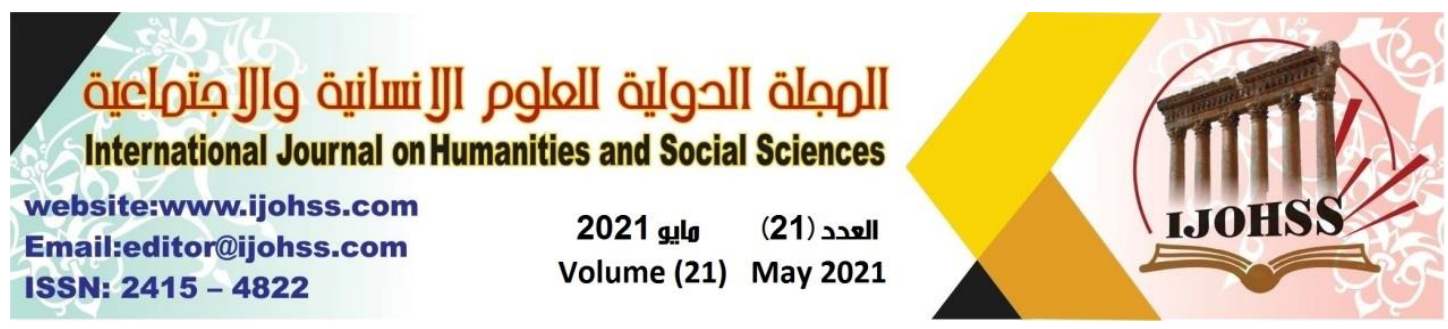

countries, but "Trump" announced his withdrawal from it on January 23, 2017, and Trump's economic policy was also repeated International with the North American Free Trade Agreement "NAFTA", The "Trump" administration was not satisfied with tampering with international trade and investment agreements. Rather, it unilaterally announced an increase in tariffs for American imports from abroad, which increase the chances of the world entering a very dangerous trade war, which may lead to economic disasters, from which the United States will suffer the most. Because it has the largest share of international trade and foreign investment in the countries of the world. "Trump's" position on environmental protection policies and facing the dangers of global warming has not changed. He decided to withdraw from the Paris Climate Agreement in mid-2017, which is the most important agreement in modern history to confront climate change resulting from human activities harmful to the environment. The "Trump" administration has strengthened this policy by canceling a number of American laws that set conditions and controls to protect the natural environment in the United States of America. Thus, the fluctuations of "Trump" political stances threaten chaos in political relations, due to the enormous size of the United States. ${ }^{(36)}$

4- A major rise in the extreme right and populist parties in the past few years: especially in the wake of the arrival of US President "Trump" to the presidency, which resulted in several elections that took place during the years (2017-2018), whether in France and Germany or in Austria, the Netherlands and other countries Its results indicate the success of populist and right-wing extremist parties in increasing their popularity, and their far-right discourse has been accepted by a large number of the public. Among the most prominent of these parties are the National Front Party in France, the Danish People's Party, the Golden Dawn Party in Greece, the Dutch "Freedom Party", the Podemos Party in Italy and the Austrian "Freedom Party". And the right-wing "Law and Justice Party" in Poland, and the "Alternative for Germany Party", which ranked third in the recent German elections and others. Moreover, populism is sweeping the world from the Philippines to the United States through Brazil recently, and before it India and Mexico. And Pakistan and Canada, led by controversial leaders, are followed by defeated peoples who have been exhausted by economic crises to destabilize political life in their countries. ${ }^{(37)}$

5- Adopting political programs and perceptions that represent a grave danger to the system and its political and economic interests: especially the Middle East region, the heart of the Islamic world. Economically, and the resultant change in the international balance of power and the influence of various interests, most notably changing the pattern and traditional form of alliances in the Middle East region, and this current was able to convince the street in Britain to leave the European Union,

${ }^{36}$ () Sami Al-Salami, Trump and the Allies Maximizing American Gains, International Politics Journal, No. (215), January 2019, Al-Ahram Foundation, Cairo, p. 93.

${ }^{37}$ () Xenia Wickett,America's International Role Under Donald Trump,Chatham House, the Royal Institute of International, London, January 2017 ,p15. 


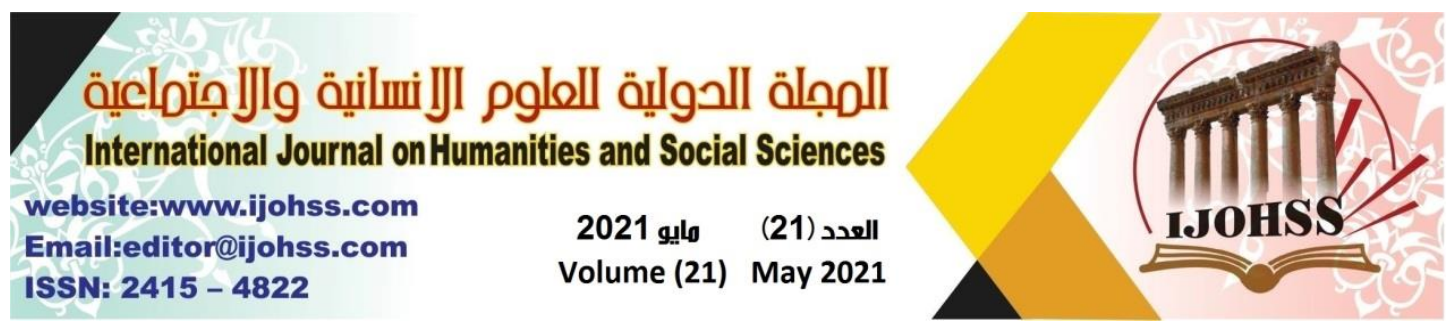

and it was also able to win in local elections and European governments, It was also able to achieve victory in local elections, European governments, and the European Parliament in many European countries, in a devastating blow to the liberal and leftist parties and currents and groups of the left and right of the center. ${ }^{(38)}$

6- The endeavor of the extreme right-wing forces to exploit the difficult events: and terrorist operations that Western powers are subjected to in order to put their ideas and opinions on the political scene and attract individuals to it. Although the extreme right differs from one country to another, they agree on several prominent points, which are their categorical rejection of immigrants and reduced opportunities Work These parties are working to reduce crime and unemployment rates by reducing the number of immigrants. ${ }^{(39)}$

7- The American philosopher "Francis Fukuyama",: after announcing the victory of "Trump" in the American presidential race at the expense of his democratic rival "Hillary Clinton", wrote a political article entitled "The United States of America versus the world" published by the "Financial Times" newspaper, in which he said That "Donald Trump's presidency" of the United States of America will herald the end of the era in which the United States was a symbol of democracy itself in the eyes of the peoples suffering under the rule of authoritarian regimes around the world. " Fukuyama and the world explained that (the Americans vote on Donald Trump as a transition from one trench to another, that is, the transition from "the camp of international liberalism to the camp of populist nationalism"). ${ }^{(40)}$

8- The phenomenon of the extreme right in the United States of America has led to the expansion and increase in the strength of the fundamentalist apostasy movement in the world: that is, the American retreat to the methodologies of militancy or national, ethnic, religious and even material intolerance, in the sense of wealth and poverty, whose page is supposed to have turned. It is a phenomenon similar in methodology to the extreme right-wing movement in Europe, the extremist nationalist currents in Russia and Turkey, and the radical Islamic fundamentalist currents in Islamic countries. ${ }^{(41)}$

\section{Results:}

1- Relations between states at the level of the international arena are subject in their provisions to the legal rules regulating international relations between members of the international community, and the provisions contained in the Charter of the United

${ }^{38}$ () Abu Ali's appeal, the United States and the extreme right worsened with the escalation of arrests linked to local terrorism, Al-Sharq Al-Awsat newspaper, No. (14860), Riyadh, August 5, 2019, p. 7.

${ }^{39}$ () Reza Muhammad Hilal, Asia and the Pacific ,Between Obama and Trump, Journal of International Politics, No. (215), Al-Ahram Foundation, Cairo, January 2019, p. 126.

${ }^{40}$ () Paul Blustein, Schism: China, America and the Fracturing of the Global Trading System, Center for International Governance Innovation, 2019

${ }^{41}$ () Katharina Pistor, The Code of Capital: How the Law Creates Wealth and Inequality, Princeton University Press, 2019 


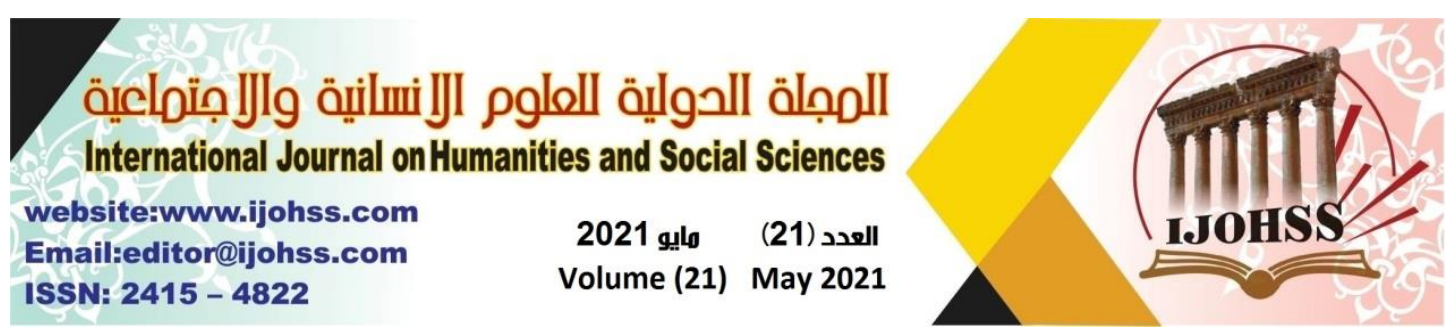

Nations of the provisions ratified by most countries of the world in order to avoid the occurrence of a third world war and to achieve the endeavor of international peace and security. Imposed by international agreements concluded in this framework, while the phenomenon of the extreme right in the United States of America threatens the existence of this security, and that only because the extreme right seeks to be The United States of America is the largest and only power in the world even if "NATO" member states abandon it. Therefore, it is necessary to reveal accordingly the reasons that led to the change in the course of modern international relations, and to change the balance of power accordingly. International events and what is happening in terms of interstate relations have become according to the requirements of the United States of America, as it is not subject in its international relations to the rules of international law, but according to the individual power relations that characterize America without other countries in the world, especially war technology, which will help it To change the course of international relations completely and as soon as possible.

2- It is clear that the attempts to establish the unipolar model have failed, and the change of the global system has become irreversible. New players seek greater influence over global and regional processes, and justifiably want greater participation in major decision-making. There is a need for a more just and inclusive system.

3 - It is clear that the confrontation cannot be reduced, confidence enhanced, and common challenges and dangers overcome in the absence of real collective efforts and the central role of the United Nations. A unified interpretation of the principles and norms of international law must be agreed upon.

4- The discourse on "liberalism", "democracy" and "human rights" is accompanied by the activation of positions based on inequality, lack of justice, selfishness and the conviction to have an exceptional role.

5- The West, and especially the United States of America, presents itself as a defender of "liberalism", At the same time, it follows the policy of sanctions, economic restrictions and military threats against a number of countries, including Cuba, Iran, Venezuela, North Korea and Syria.

6- How can talk about protecting human rights be combined with bombing sovereign states and following a deliberate approach aimed at destroying states?

7- Using unilateral steps to solve global issues is doomed to failure, and the global system that the West is working to activate aims to reconsider the basic international legal mechanisms, and is unable to find viable solutions in the long run.

8- The West's attempts to activate the "rule-based system" violate the powers of the United Nations, and the West is trying to seize the powers of international organizations to achieve its interests that are outside the framework of international mechanisms.

9- The American policies aim to reconsider all basic agreements on strategic stability. In this context, the United States withdrew from the Missile Defense Treaty and the Intermediate and Short-Range Missile Treaty. And Washington's withdrawal from the 


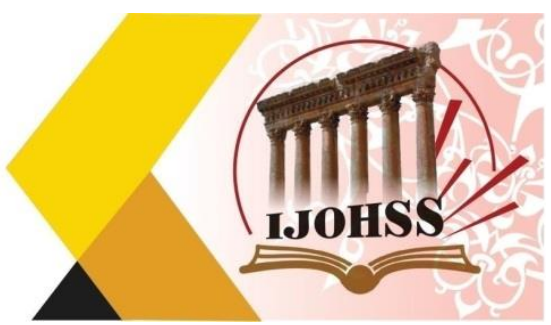

nuclear agreement with Iran and Washington's refusal to implement UN Security Council resolutions on the settlement between the Israelis and the Palestinians.

10- Washington has begun implementing plans to deploy weapons in space, and rejects proposals for a comprehensive suspension of this activity.

11- On the economic level, the United States sets up protection barriers and imposes sanctions as a main method for commercial transactions and uses American laws outside its jurisdiction.

12- The United States is trying to "recruit" all its partners abroad to deter Russia and China, and does not hide its desire to undermine regional structures and organizations in Eurasia and the Asia-Pacific region, which are developing outside American control.

\section{Conclusions:}

Tracking the phenomenon of the extreme right through its historical stages shows the lack of agreement on a fixed formula that defines this phenomenon, but most studies agree that it is a unified intellectual system that expresses its anti-immigration and anti-immigrant programs, and their perception that they threaten national identity, and a major cause of unemployment, crime and other manifestations of insecurity Social, and exploitation of what the welfare state provides, to contribute to several political, social and economic approaches to its emergence at the international level.

The rise and prominence of this phenomenon in its influential form with the victory of "Donald Trump" in the presidency in the United States of America in 2016, to consolidate this phenomenon and revive it in its new form internationally, to cover its repercussions in the rise of fanatic extremist religiously, nationally and racially in many countries of the world. The subjectivity of human societies, and the breach of international agreements, and then the isolation, fossilization and racist positions on contemporary issues, through the adoption of these currents programs and perceptions that represent a grave danger to the system of the international political system and international relations.

\section{References}

1. Abu Ali's appeal, the United States and the extreme right worsened with the escalation of arrests linked to local terrorism, Al-Sharq Al-Awsat newspaper, No. (14860), Riyadh, August 5, 2019, p. 7.

2. Abu Bakr El-Desouky, Trump's America .. Profit and Loss Accounts, International Politics Journal, No. (215), Al-Ahram Foundation, Cairo, January 2019, p. 82.

3. Ahmed Haider Abdul-Ridha, The UK's withdrawal from the European Union, its mechanisms and effects, unpublished Master Thesis, Faculty of Law and Political Science, Beirut Arab University, Beirut, 2019, p. 33. 


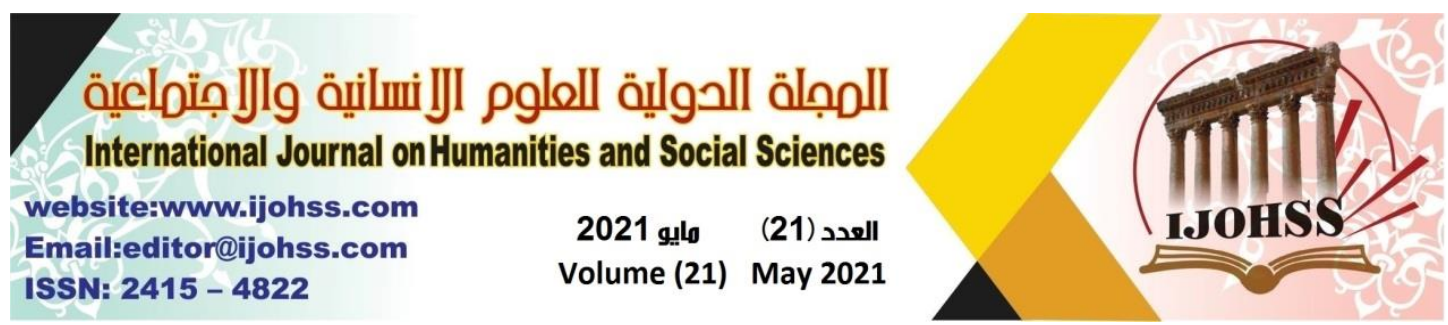

4. Al-Jabri, Extremist Right Parties in Europe: A Study in Ideas and the Political Role, Journal of International Studies, No. (35), 2008, Center for Strategic and International Studies, University of Baghdad, Baghdad, p. 47. Looking also, Nazem Abdel-Wahid Al-Jassour, European Right Parties between Accounts of the Past and Future Prospects, European Papers, Center for International Studies, University of Baghdad, 2000, pp. 4-7

5. Amin Saadawi and Masoud El-Sassi, The Ascension of Right Populations in the West 2016/2017 AD - USA - Model - Unpublished Master Thesis, Faculty of Law and Political Science, University of the Martyr Hama Lakhdar - El-Wadi, Algeria, 2018, p. 67

6. Azmi Bishara, Rise of the Right and Importing the Clash of Civilizations into the Interior: When Democracy Brings Antipods to Liberalism, Arab Politics Magazine, Issue (23), Arab Center for Research and Policy Studies, Doha, November 2016, p. 8

7. Bruno Maçães, The Dawn of Eurasia: On the Trail of the New World Order, Penguin Random House, 2018

8. Dominic Vidal, European Extremist Right Movements: Strategies and Identities, in the book, Situations of the World 2012, new players ... and a new reality, translation: Hoda Munqas, Arab Thought Foundation, Beirut, 2012, p. 81.

9. For more see: Mohamed Kamal, Trump and the future of the international system, Journal of International Politics, No. (215), Al-Ahram Foundation, Cairo, January 2019, pp. 88-90. Likewise, it is considered in: Yahya Saeed Qaoud and Ola Amer Al-Jaab ,0, previously mentioned source, p. 140

10. Katharina Pistor, The Code of Capital: How the Law Creates Wealth and Inequality, Princeton University Press, 2019

11. Mansour Hussain, The Rise of the Extremist Right in Europe, Progressive Forum Kingdom of Bahrain, January 9, 2017, see: http://www.altaqadomi.org/?p=1311

12. Maram Zeia, the European-American right ... a bridge or a dilemma?, Journal of International Politics, No. (215), Al-Ahram Foundation, Cairo, January 2019, pp. 123 123.

13. Maurice Devergie, Political Parties, Translation: Ali Muqallad and Abdel-Hassan Saad, Dar Al-Nahar Publishing, Beirut, 1983, p. 5, and also looks at: Abu Bakr AlDesouki, The Dialectical Relationship between Islamophobia and the European Right, Journal of International Politics, No. (208), , Al-Ahram Foundation, Cairo, April 2017, p. 85.

14. Mona Khwais, The Men of Balconies An Analytical Study of the Populist Phenomenon, Dar Al-Farabi, Beirut, 2012, pp. 27-30.

15. Muhammad Al-Hajiri, Dialogue with Ali Harb, Al-Faisal Magazine, Issues (479480), King Faisal Center for Research and Islamic Studies, Riyadh, September 2016, p. 107. For more, see Sherif Nessim Qaltet Bakhit, the refugee crisis and the rise of the extreme right in Europe, European Center for Counter-Terrorism and Intelligence Studies, Germany, July 13, 2018. https://www.europarabct.com/ 


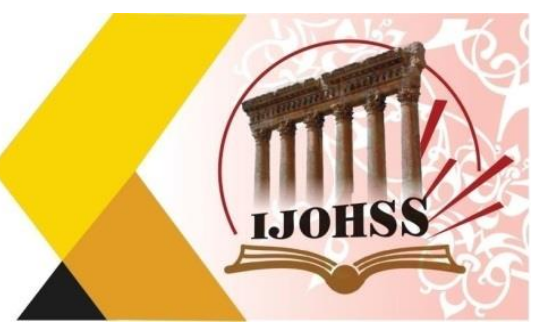

16. Naji Abdel-Nour, Muslim Communities in Europe and the extent of their integration into political work in light of the rise of extreme right parties, in the book Islamophobia in Europe: Discourse and Practice, Arab Democratic Center for Strategic, Political and Economic Studies, Berlin, 2019, pp. 149-150.

17. Nicholas Lardy, The State Strikes Back: The End of Economic Reform in China, Peterson Institute for International Economics, 2019

18. Noman Abdul-Razzaq Al-Samarrai, targeting Arabs and Muslims, Al-Faisal Magazine, Issue (1268), King Faisal Center for Research and Islamic Studies, Riyadh, February / March 2007, p. 94.

19. Patrick Diamond, The Crisis of Globalization: Democracy, Capitalism and Inequality in the Twenty-First Century, IB Tauris, 2019

20. Paul Blustein, Schism: China, America and the Fracturing of the Global Trading System, Center for International Governance Innovation, 2019

21. Peter Bergen, Trump and His Generals: The Cost of Chaos, Penguin Press, December 2019 pp. 44

22. Rabeh Zoghouni, Islamophobia and the Rise of the Extremist Right in Europe: Sociocultural Approach, Arab Future Magazine, Volume (36), No. (421), Center for Arabic Unity Studies, Beirut, March 31, 2014, p. 124.

23. Rabeh Zoghouni, Islamophobia and the Rise of the Extremist Right in Europe: A Sociocultural Approach, previously mentioned source, p. 128.

24. Reza Muhammad Hilal, Asia and the Pacific ,Between Obama and Trump, Journal of International Politics, No. (215), Al-Ahram Foundation, Cairo, January 2019, p. 126.

25. Right-wing current in the West: Ascension and Influence, Political Papers, Strategic Thought Center for Studies, Beirut, 2018, p. 4.

26. Rinas Penafi, The Rise of the Extreme Right, Reasons and Implications: An Analytical Study, Arab Democratic Center, Berlin, May 12, 2017, https://democraticac.de/?p=46400

27. Robert Kaplan, The Return of Marco Polo's World: War, Strategy, and American Interests in the Twenty-First Century, Random House, 2018

28. Russell Muirhead and Nancy L Rosenblum, A Lot of People Are Saying: The New Conspiracism and the Assault on Democracy, Princeton, 2019

29. Saeed Kazem Bishara, The Extremist Right in Europe: A Political-Social Study of Reasons and Dimensions, Unpublished Master Thesis, College of Political Science, Al-Mustansiriya University, Baghdad, 2014, p. 7.

30. Sami Al-Salami, Trump and the Allies Maximizing American Gains, International Politics Journal, No. (215), January 2019, Al-Ahram Foundation, Cairo, p. 93.

31. Sherine Hamed Fahmy, The Rise of the Extremist Right in Europe Between Cultural and Political and Economic Interpretation, The Civilization Center for Studies and Research, Cairo, considers: http://hadaracenter.com/pdfs/ 


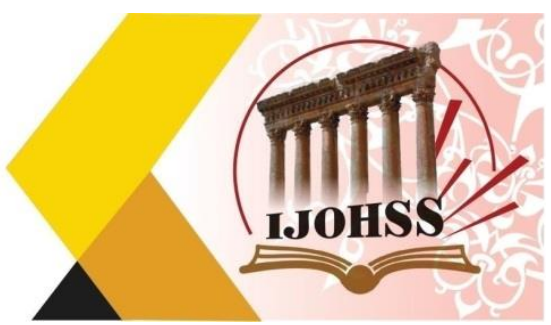

32. Simon Reid-Henry, Empire of Democracy: The Remaking of the West Since the Cold War, 1971-2017, Simon \& Schuster, 2019

33. The Rise of the Extreme Right in Europe: The Most Important Factors, Characters, and Ideas, previously mentioned source, p. 6.

34. The rise of the extreme right in Europe: the most prominent factors, personalities and ideas, Directorate of Strategic Studies, No. (35), Consultative Center for Studies and Documentation, Beirut, May 2019, p. 8.

35. The Rise of the Extremist Right in Europe: The Most Important Factors, Characters, and Ideas, a previously mentioned source, p. 9. See also: The Right Right in the West Ascension and Influence, a previously mentioned source, p. 8.

36. Ulrich Beck, Power and Counter-Authority in the Era of Globalization, translated by George Kattoura and Elham Shaarani, The Eastern Library, Beirut, 2010, pp. 1112

37. Walid Jasad Al-Zaidi, The Consequences of the emergence of populism in the West, Arab Thought Foundation, Saudi Arabia, May 8, 2019, see: https://arabthought.org/. Likewise, it looks at: the Charter of Manahi Al-Issawi, the growth of populist currents between excessive democracy and government failure, Center for Strategic Studies / Department of International Studies, University of Karbala, July 2016, seen: http://kerbalacss.uokerbala.edu.iq/

38. Xenia Wickett,America's International Role Under Donald Trump,Chatham House, the Royal Institute of International, London, January 2017 ,p15.

39. Yahya Saeed Qaoud and Ola Amer Al-Jaab, US National Security Document 2017 An Analytical Reading of Donald Trump's Strategy, Strategic Readings, Issue (20), Palestinian Planning Center, Palestine Liberation Organization, Gaza, April 2018, p. 21.

40. Yaman Annan, the implications of the rise of the extreme right in Europe, research papers, Al-Badil Center for Planning and Strategic Studies, Amman, 19 December 2016.

41. Yemeni Atef Mohamed, The Rise of the Extremist Right Parties in Europe: A Case Study of France in the Period "1984 - 2017, Arab Democratic Center, Berlin, August 19, 2019, see: https://democraticac.de/?p=62037 